University of Nebraska - Lincoln

DigitalCommons@University of Nebraska - Lincoln

Agronomy \& Horticulture -- Faculty Publications

Agronomy and Horticulture Department

$10-1970$

\title{
Sweetclover Weevil Feeding Stimulants: Variation in Levels of Glucose, Fructose, and Sucrose in Melilotus Leaves
}

W. R. Akeson

H. J. Gorz

Francis A. Haskins

University of Nebraska-Lincoln, fhaskins@neb.rr.com

Follow this and additional works at: https://digitalcommons.unl.edu/agronomyfacpub

Part of the Plant Sciences Commons

Akeson, W. R.; Gorz, H. J.; and Haskins, Francis A., "Sweetclover Weevil Feeding Stimulants: Variation in Levels of Glucose, Fructose, and Sucrose in Melilotus Leaves" (1970). Agronomy \& Horticulture -- Faculty Publications. 297.

https://digitalcommons.unl.edu/agronomyfacpub/297

This Article is brought to you for free and open access by the Agronomy and Horticulture Department at DigitalCommons@University of Nebraska - Lincoln. It has been accepted for inclusion in Agronomy \& Horticulture -Faculty Publications by an authorized administrator of DigitalCommons@University of Nebraska - Lincoln. 


\title{
Sweetclover Weevil Feeding Stimulants: Variation in Levels of Glucose, Fructose, and Sucrose in Melilotus Leaves ${ }^{1}$
}

\author{
W. R. Akeson, H. J. Gorz, and F. A. Haskins ${ }^{2}$
}

\section{ABSTRACT}

Youngest fully expanded leaves, from plants of $M$. officinalis (L.) Lam. seeded at weekly intervals but harvested on the same day, were approximately 1.5 to 2.0 times as high in content of glucose, fructose, and sucrose at all stages of growth as leaves from comparable plants of $M$. infesta Guss. These plants varied in age from 3 to 14 weeks. Levels of glucose and fructose increased with increasing plant age in both species. Sucrose content in. creased in $M$. officinalis but decreased in $M$. infesta as the plants matured. When plants of approximately the same age were sampled at six different dates, the level of each sugar again was higher in young leaves of $M$. off $i$ cinalis than in corresponding leaves of $M$. infesta at each sampling date. Evidence reported in this and preceding papers suggests that differences in sugar content may influence the degree of resistance or susceptibility of Melilotus leaves to feeding by the adult sweetclover weevil (Sitona cylindricollis Fahraeus), but that these differences apparently are not primarily responsible for the observed differences in resistance displayed by $M$. officinalis and M. infesta.

Additional index words: Sitona cylindricollis, Sugars, Insect resistance.

$\mathrm{F}^{\mathrm{E}}$ EEDING by the adult sweetclover weevil, Sitona cylindricollis (Fahraeus) was stimulated by a water-soluble fraction extracted from Melilotus leaves $(4,6)$. The feeding stimulant, designated Stimulant $A$, was found in chromatographically purified leaf extracts from the weevil-resistant Melilotus infesta Guss., as well as from a susceptible species, $M$. officinalis (L.) Lam. Stimulant A was subsequently fractionated into three feeding stimulants which were identified as glucose, fructose, and sucrose (3). The isolated compounds and corresponding reagent grade sugars were identical in chromatographic and chemical behavior, and also in feeding stimulant activity as measured with the sweetclover root disk bioassay (7). Sucrose stimulated the greatest amount of feeding when the three sugars were compared at equal concentrations in the same bioassay (3). Disks treated with glucose and fructose were fed upon equally at the three concentrations tested.

Sweetclover weevil resistance apparently depends upon a balance between feeding stimulants and feeding deterrents; and the relative contributions of the different factors vary considerably with stage of leaf and plant development (1). Information concerning

\footnotetext{
${ }^{1}$ Contribution from the Nebraska Agricultural Experiment Station, Lincoln, Neb., and the Crops Research Division, ARS, USDA. Supported in part by Crops Research Division and Entomology Research Division, Agric. Res. Serv., USDA Grant No. 12-14-100-8027 (33). Published with the approval of the Director as Paper No. 2687, Journal Series, Nebraska Agr. Exp. Sta. Received Dec. 4, 1969.

${ }^{2}$ Formerly Assistant Professor of Agronomy, University of Nebraska (present address, Great Western Sugar Co., Longmont, Colo.); Research Geneticist, Grops Research Division, ARS, USDA; and Bert Rodgers Professor of Agronomy, University of Nebraska, respectively, Lincoln, Neb., 68503. The technical assistance of Patricia Underwood and Henry J. Stevens is gratefully acknowledged.
}

the relative amounts of the three sugars acting as feeding stimulants in sweetclover leaves would aid in determining the role of these sugars in the mechanisms of resistance and susceptibility of Melilotus plants to weevil feeding. Levels of glucose, fructose, and sucrose in resistant and susceptible plants of various ages are reported in this paper.

\section{MATERIALS AND METHODS}

Plantings consisting of 10 plants of $M$. infesta (Nebraska strain M70) and 10 of $M$. officinalis 'Goldtop' (F.C. 38,923) were made in a greenhouse at weekly intervals for 13 weeks, to permit comparison of the sugar content of similar leaves of the two species from plants of varying ages. Natural light was supplemented with cool white fluorescent lamps to provide a 16-hr photoperiod. Sampling and extraction of leaves from plants 3 to 14 weeks of age was accomplished in one afternoon, following 5 consecutive sunny days. The youngest fully expanded leaf from each of the 10 plants of similar age and species was harvested, and these 10 leaves were bulked. One week after the initial harvest, the newly formed youngest fully expanded leaves were similarly harvested and extracted, again after at least five consecutive days of sunshine. For example, the 10 plants of $M$. infesta from which the first 8-week sample was taken, were used one week later as the source of material for the second 9 -week sample. Thus, there were two samples representing each plant age. Following the harvest of leaves from the 10 plants of a group, the three leaflets of each leaf were removed from the petiole. Mid-leaflets, used for the determination of dry matter percentage, were weighed before and after drying at 110 C for 6 hours. The 20 side leaflets were weighed, washed with water, dropped into $10 \mathrm{ml}$ boiling water and autoclaved at 120 C for 20 min. Autoclaved extracts were cooled, leaflets were removed and discarded, and the extracts were stored in a freezer for later assay.

Additional plantings of both species were made every 3 to 4 weeks, so that several extractions over a period of 3 months could be made on plants of approximately the same age. Ten plants of each species, from 5 to 8 weeks of age, were sampled at each of six harvest dates. All sampling and extraction was done during the afternoons of days having full sunshine. The youngest fully expanded leaf from each plant was harvested individually. Mid-leaflets were used for the determination of dry matter percentage, while the two side leaflets were weighed, dropped into $2 \mathrm{ml}$ boiling water, and autoclaved at $120 \mathrm{C}$ for $20 \mathrm{~min}$. Extracts were stored in a freezer for later assay.

In order to remove compounds interfering with the sugar determinations, crude extracts were partially purified by preparative paper chromatography in a manner similar to that described previously $(4,6)$. Chromatograms were developed with a solvent composed of isopropyl alcohol, ethyl acetate, and water $(8: 1: 3, v / v / v)$. Glucose, fructose, and sucrose were confined to a single band extending from $\mathbf{R f} 0.30$ to 0.52 ; this band was eluted with water. Thin-layer chromatography of the eluates, using the procedure described by Akeson et al. (3), indicated that glucose, fructose, and sucrose were the only sugars present, and that other interfering reducing compounds had been effectively removed.

Eluates were assayed for glucose and fructose content by means of a modification of the colorimetric method described by Ting (9). Total reducing sugars were determined by first mixing $1 \mathrm{ml}$ of eluate (representing 1 to $3 \mathrm{mg}$ of dry leaf tissue) with $1 \mathrm{ml}$ of alkaline ferricyanide solution in an $18 \times 150 \mathrm{~mm}$ test tube and heating the mixture in a boiling water bath for $10 \mathrm{~min}$. The tube was then cooled in cold water, and $2 \mathrm{ml}$ of $2 N$ sulfuric acid and $0.8 \mathrm{ml}$ of arsenomolybdate solution were added. Absorbance of the solution was read at $515 \mathrm{~nm}$ with a blank consisting of a similarly treated eluate from a chromatogram to which no extract had been applied. Apparent fructose content was determined by the same procedure described for 
total reducing sugars, except that the mixtures of cluate and ferricyanide were incubated at 55 C for $30 \mathrm{~min}$. Glucose and fructose contents were calculated from the total reducing sugars and apparent fructose values by the equation of Ting (9).

A modification of the resorcinol procedure described by Kulka (8) was used to determine sucrose. One $\mathrm{ml}$ of cluate was mixed with $3 \mathrm{ml}$ of $30 \% \mathrm{HCl}$ (containing $0.216 \mathrm{~g} /$ liter $\mathrm{FeNH}_{4}\left(\mathrm{SO}_{4}\right)_{2} \cdot 12$ $\mathrm{H} . \mathrm{O}$ ) and $3 \mathrm{ml}$ of $0.05 \%$ resorcinol $(\mathrm{w} / \mathrm{v}$ in absolute ethanol). The mixture was heated at $73 \mathrm{C}$ for 1 hous, cooled, and read at $480 \mathrm{~nm}$. The reading obtained provided a measure of total fructose residues (free fructose plus the fructose component of sucrose). Calculation of sucrose content was based on the difference between total fructose residues and the actual fructose content (obtained from the reducing sugar procedure described in the preceding paragraph).

The efficiency of the above procedures was studied in preliminary experiments involving recovery of glucose, fructose, and sucrose added to crude extract. Recoveries were 95 to $99 \%$ for glucose, 93 to $94 \%$ for fructose, and 98 to $100 \%$ for sucrose.

\section{RESULTS AND DISGUSSION}

Average contents of glucose, fructose, sucrose, and total sugars (sum of glucose, fructose, and sucrose) in the youngest fully expanded leaves of $M$. infesta and $M$. officinalis plants from 3 to 14 weeks of age are presented in Fig. 1. Each value in the graph represents the mean of two extracts (one extract from each of the two samples representing each plant age). Triplicate chromatograms of each extract were prepared, developed, and assayed.

At all ages, the content of each of the sugars was consistently higher in leaves of $M$. officinalis than in corresponding $M$. infesta leaves. In $M$. officinalis leaves, glucose, fructose, sucrose, and total sugar contents, averaged for all plant ages, were $1.8,1.4,1.9$, and 1.7 times as high, respectively, as the averages for corresponding $M$. infesta leaves. In addition, the content of each sugar, with the exception of sucrose in $M$. infesta, tended to increase with increasing plant age. The contents of glucose and fructose were higher in leaves of older $M$. infesta plants than in leaves of young plants of $M$. officinalis. The sucrose content of $M$. infesta increased slightly as the young plants grew, remained about the same during the intermediate period of growth, and then decreased rather sharply as the plants matured.

The contents of sugars from plants of approximately the same age harvested at six different dates are summarized in Table 1. Determinations on extracts from 10 individual plants contributed to each mean. For each extract, a single chromatogram was run, and the three sugars were cletermined in the eluate of the appropriate section from each chromatogram. As was true for the data in Fig. 1, the average level of each sugar was higher in leaves of $M$. officinalis than in $M$. infesta leaves at each sampling date. Relative differences varied at different sample dates, ranging, in most cases, from contents that were $11 / 2$ to 2 times as high in the youngest fully expanded leaves of $M$. officinalis as in corresponding leaves of $M$. infesta plants harvested at the same time. Contents of individual sugars also varied widely with sampling date within the same species. These differences were doubtless due, in part, to the changing conditions in the greenhouse from February to May. Despite these variations in sugar content, a clear difference between the species was observed at each sampling date.

Previous work has shown a positive relationship between concentration of glucose, fructose, and sucrose (3) or stimulant A (6) and extent of weevil feeding. However, if sugars alone were responsible for the great difference in weevil feeding between $M$. infesta and $M$. officinalis, a very large difference in sugar content would be required, rather than the two-fold difference observed in the present study. Thus, other factors must play an important role in determining the resistance of $M$. infesta. It has been

Table 1. Sugar contents of youngest fully expanded leaves harvested over a period of three months in the spring of 1969 from 5- to 8-week old, greenhouse-grown plants of $M$. officinalis and M. infesta.

\begin{tabular}{|c|c|c|c|c|c|}
\hline \multirow{2}{*}{$\begin{array}{l}\text { Melilotus } \\
\text { species }\end{array}$} & \multirow{2}{*}{$\begin{array}{c}\text { Date } \\
\text { sampled }\end{array}$} & \multicolumn{4}{|c|}{ Contert of sugar, of dry weight" } \\
\hline & & Glucose & Fructose & Sucrose & Total \\
\hline$\frac{M}{M} \frac{\text { officinalis }}{\text { infesta }}$ & $2 / 19$ & $\begin{array}{l}1.08 \div 0.06 \\
0.86 \pm 0.03\end{array}$ & $\begin{array}{l}0.81 \pm 0.07 \\
0.61 \pm 0.04\end{array}$ & $\begin{array}{l}1.59 \pm 0.22 \\
0.84 \pm 0.10\end{array}$ & $\begin{array}{l}3.37 \pm 0.25 \\
2.30 \pm 0.12\end{array}$ \\
\hline$\frac{\mathrm{M} .}{\mathrm{M}} \cdot \frac{\text { officinal is }}{\text { infesta }}$ & $3 / 4$ & $\begin{array}{l}1.14 \pm 0.10 \\
0.79 \pm 0.08\end{array}$ & $\begin{array}{l}0.95 \pm 0.13 \\
0.80 \pm 0.09\end{array}$ & $\begin{array}{l}2.04 \pm 0.14 \\
1.37 \pm 0.13\end{array}$ & $\begin{array}{l}4.14 \div 0.31 \\
2.96 \pm 0.22\end{array}$ \\
\hline$\stackrel{\mathrm{M}}{\mathrm{M}} \cdot \underline{\text { officinal is }}$ & $3 / 18$ & $\begin{array}{l}1.37 \pm 0.11 \\
0.88 \pm 0.12\end{array}$ & $\begin{array}{l}1.21 \pm 0.09 \\
0.70 \pm 0.07\end{array}$ & $\begin{array}{l}2.51 \neq 0.29 \\
1.69 \neq 0.22\end{array}$ & $\begin{array}{l}5.08 \pm 0.24 \\
3.28 \pm 0.22\end{array}$ \\
\hline$\frac{M}{M}$. officinalis & $4 / 2$ & $\begin{array}{l}1.98 \pm 0.25 \\
1.18 \pm 0.35\end{array}$ & $\begin{array}{l}1.82+0.22 \\
0.97 \pm 0.26\end{array}$ & $\begin{array}{l}2.18 \div 0.23 \\
0.94 \div 0.24\end{array}$ & $\begin{array}{l}5.97 \pm 0.57 \\
3.09 \pm 0.62\end{array}$ \\
\hline$\frac{\mathrm{M}}{\mathrm{M}} \cdot \frac{\text { officinalis }}{\text { infesta }}$ & $4 / 30$ & $\begin{array}{l}1.70 \pm 0.14 \\
1.13 \pm 0.07\end{array}$ & $\begin{array}{l}1.39 \pm 0.13 \\
0.99 \pm 0.12\end{array}$ & $\begin{array}{l}1.53 \pm 0.08 \\
0.50 \pm 0.10\end{array}$ & $\begin{array}{l}4.62 \pm 0.31 \\
2.62 \pm 0.18\end{array}$ \\
\hline $\begin{array}{l}\text { M. officinalis } \\
\text { M. infesta }\end{array}$ & $5 / 20$ & $\begin{array}{l}1.59 \pm 0.15 \\
0.82 \pm 0.12\end{array}$ & $\begin{array}{l}1.15 \pm 0.11 \\
0.64 \pm 0.04\end{array}$ & $\begin{array}{l}1.70 \div 0.16 \\
0.71 \pm 0.11\end{array}$ & $\begin{array}{l}4.32 \pm 0.38 \\
2.15 \pm 0.15\end{array}$ \\
\hline
\end{tabular}

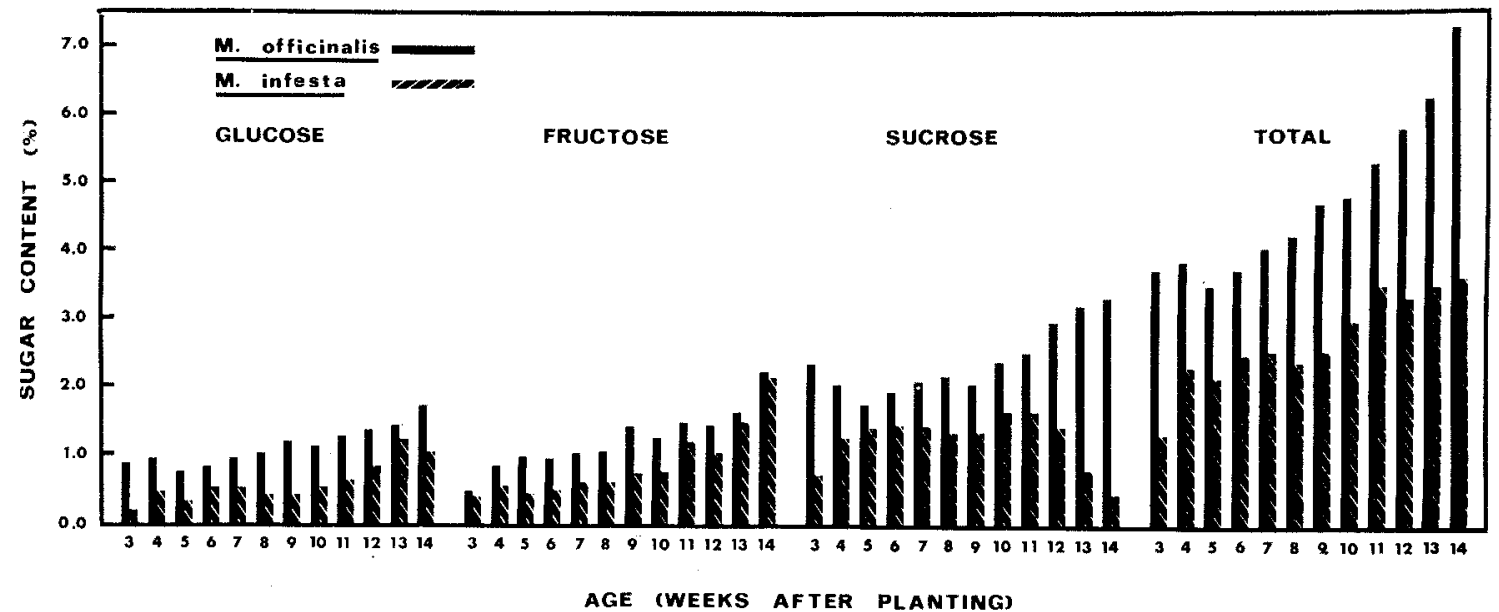

Fig. 1. Contents of glucose, fructose, sucrose, and total sugars (sum of glucose, fructose, and sucrose) of youngest fully expanded leaves of $M$. officinalis and $M$. infesta plants from 3 to 14 weeks of age. 
proposed that nitrate level is the factor of greatest importance, at least in young leaves $(1,2,5)$. Such leaves in $M$. infesta contained more than 10 times as much nitrate as young $M$. officinalis leaves (2). The stimulatory effect of a higher sugar content would tend to overcome the resistance conferred by a given amount of nitrate, and thus render the plant more susceptible to weevil feeding. Conversely, a lower level of sugars would decrease susceptibility. The observed differences in sugar content between species permit a fuller understanding of the observation reported previously $(1,2)$, that a higher level of nitrate was required in $M$. officinalis leaves for a given level of resistance than in $M$. infesta leaves of the same age. Resistance and susceptibility, therefore, are influenced by the balance between factors that stimulate feeding and those that deter feeding.

\section{LITERATURE CITED}

1. Akeson, W. R., G. L. Beland, F. A. Haskins, and H. J. Gorz. 1969. Influence of developmental stage on the resistance of
Melilotus infesta leaves to feeding by the sweetclover weevil. Crop Sci, 9:667-669.

2. - - - - - , and G. R. Manglitz. 1969. Nitrate as a deterrent to feeding by the sweetclover weevil. J. Econ. Entomol. 62:1169-1172.

3. - - H. J. Gorz, and F. A. Haskins. 1969. Sweetclover weevil feeding stimulants: Isolation and identification of glucose, fructose, and sucrose. Crop Sci. 9:810-812.

4. - - - - - - , - - - and G. R. Manglitz. 1968. A watersoluble factor in Melilotus officinalis leaves which stimulates feeding by the adult sweetclover weevil. J. Econ. Entomol. 61:1111-1112.

5. - - , F. A. Haskins, and H. J. Gorz. 1969. Sweetcloverweevil feeding deterrent B: Isolation and identification. Science 163:293-294.

6. - _ _ _ _- _- and G. R. Manglitz. 1968. Watersoluble factors in Melilotus leaves which influence feeding by the sweetclover weevil. Crop Sci. 8:574-576.

7. _-_, G. R. Manglitz, H. J. Gorz, and F. A. Haskins. 1967. A bioassay for detecting compounds which stimulate or deter feeding by the sweetclover weevil. J. Econ. Entomol. 60: 1082-1084.

8. Kulka, R. G. 1956. Colorimetric estimation of ketopentoses and ketohexoses. Biochem. J. 63:542-548.

9. Ting, S. V. 1956. Rapid colorimetric methods for simultaneous determination of total reducing sugars and fructose in citrus juices. J. Agr. Food Chem. 4:263-266. 